\title{
Student and family factors that are associated with Grade 4 reading achievement in Azerbaijan
}

\author{
LALA GANIYEVA*
}

Development Research Center, Baku, Azerbaijan

\section{RESEARCH PAPER}

Received: October 10, 2020 • Accepted: January 31, 2021

Published online: April 10, 2021

(c) 2021 The Author(s)

\begin{abstract}
.
Aims of the study: Compared to other developing countries, the reading achievement of Azerbaijani students remains low. Using the Progress in International Reading Literacy Study (PIRLS) 2016 data, this study examines potential predictors of Grade 4 student reading achievement in Azerbaijan. Background of the research: The study is guided by an exploratory model and considers various student and family factors which could be influenced by the policies to improve student reading achievement in Azerbaijan. The study differs from previous research in that it simultaneously examines multiple predictors of student reading achievement in a previously under-researched country. Method: This study conducts a secondary analysis of the PIRLS 2016 data. Regression model is utilized to examine the effects of student and family factors on reading achievement. Results: The study finds that student characteristics (gender, liking reading, and confidence in reading) and family factors (home resources for learning, preschool attendance) are significantly associated with reading achievement of Grade 4 students in Azerbaijan. The model explains $17 \%$ of the variance in student reading achievement. Conclusion: This study discusses recommendations related to the effects of various factors on reading literacy scores.
\end{abstract}

\section{KEYWORDS}

PIRLS 2016, Azerbaijan, reading achievement, Grade 4, international assessment, foreign countries, achievement tests

\footnotetext{
*Corresponding author. E-mail: lganiyeva@yahoo.com
} 


\section{INTRODUCTION}

Reading literacy is an essential tool to functioning in modern society. People with good literacy skills get better jobs, perform better at work, and have better career opportunities. Therefore, examination of the factors that influence reading literacy is particularly important.

Since reading is the basis for any student's ability to succeed in modern society, many countries have made it a goal to improve student proficiency in reading. Administered every five years since 2001, the Progress in International Reading Literacy Study (PIRLS) study assesses and compares student reading performance in their fourth year of schooling. In 2016, 50 countries participated in PIRLS. The PIRLS 2016 findings showed that Azerbaijani students displayed low performance in reading literacy. Students in Azerbaijan lag behind their peers in other developing countries, in particular Kazakhstan (536) and Georgia (488). Although a mean score of Azerbaijani students in PIRLS 2016 was 472 and Azerbaijani student performance increased by 10 points since 2011 , the score was statistically significantly below the PIRLS Scale Center Point of 500. These results drew the attention of policymakers and educators and presented additional evidence for the importance of improvement of education quality in Azerbaijan.

The Ministry of Education (MoE) of Azerbaijan has paid significant attention to improving students' reading knowledge, skills, and performance. After the first participation of Azerbaijani students in PIRLS in 2011, several measures aimed at improving reading achievement and teaching reading were implemented, e.g. improvement of teacher training programs, implementation of the new National Curriculum, introduction of modern reading techniques in Azerbaijan's national language curriculum, and special reading initiatives, including implementation of Zardabi-Development of Primary School Students' Reading Skills project (Mullis, Martin, Goh, \& Prendergast, 2017).

However, policies to improve student learning need to be accompanied by research efforts to have the desired effect. Given the importance of student and family factors, an examination of their association with student reading performance will likely produce information useful for policy development for the improvement of reading achievement in Azerbaijan.

Researchers used different conceptual models for examination of factors that influence educational outcomes. The present study is guided by an exploratory model and considers various student and family factors which could be influenced by the policies to improve student reading achievement in Azerbaijan. The following paragraphs describe prior research on predictors of student reading performance included in the study.

Many studies have examined the influence of various student and family factors on reading achievement. Empirical research has demonstrated that gender and positive attitudes toward reading have positive impact on student learning to read and reading achievement (Costa, Almeida, \& Araujo, 2013; Geske \& Ozola, 2008; Leino, Linnakyla, \& Malin, 2004; Linnakyla, Malin, \& Taube, 2004; Sainsbury \& Schagen, 2004; van der Voort, 2001). Research indicates that student gender is associated with reading achievement: girls perform better than boys in reading (Ma, 2008; Perie, Grigg, \& Donahue, 2005; Wagemaker, Taube, Munck, KontogiannopoulouPolydorides, \& Martin, 1996). The attitudes toward reading are among the important factors that influence student reading performance. In $20 \mathrm{EU}$ countries, liking reading impact positively student reading performance (Costa et al., 2013). The interest of reading and engagement in reading on their own play an important role in improving reading achievement (Linnakyla et al., 
2004). Furthermore, the positive effects of attitudes towards reading on reading achievement are stronger for elementary school students than for older students (Petscher, 2010).

Student self-beliefs are important predictors of reading achievement. Reading self-concept is significantly related to reading fluency (Quirk, Schwanenflugel, \& Webb, 2009). Among other factors, reading self-efficacy is found to be significant in predicting reading achievement of Hong Kong pupils in the PIRLS 2011 study (Cheung, Lam, Au, \& So, 2017). Student self-concept is associated with student reading performance in the PIRLS 2006 study (Alivernini, 2013).

Empirical studies found positive associations of one of the family factors (home resources for learning) with student reading performance (Geske \& Ozola, 2008; Linnakyla et al., 2004; Park, 2008). Home resources for learning were found to predict student performance in PIRLS 2006 study (Alivernini, 2013). In Denmark, Sweden and France, home resources for learning were strongly associated with student achievement in reading (Costa \& Araujo, 2018).

However, empirical studies that examined the relationship between another family factor (preschool attendance) and reading achievement are mixed (Costa et al., 2012; Hogrebe \& Strietholt, 2016; Schleicher, 2014). Using PIRLS 2011 data, Hogrebe \& Strietholt (2016) examined the effect of preschool non-participation on reading achievement in eight countries; in six countries preschool attendance was not associated with achievement. Using PIRLS 2011 data for 20 European countries, Costa et al. (2012) found positive associations of preschool participation with student reading achievement for three countries in the sample. Evidence for the importance of preschool attendance for student achievement is still inconclusive, and debate of the importance of preschool attendance continues to emerge.

\section{RESEARCH QUESTIONS}

Even though existing literature has frequently examined different predictors of student performance, few empirical studies, particularly studies done in developing countries simultaneously considered multiple student and family characteristics that influence achievement. To the best of our knowledge, no studies investigated the effects of student and family factors on reading achievement of Grade 4 students in Azerbaijan. Understanding associations of student and family factors with student reading performance is critical for enhancing our knowledge of how these factors contribute to improved student learning. The present study fills the gap in the current literature and simultaneously examines multiple predictors of student reading achievement in a previously under-researched country.

The following research question is addressed in the study:

Which student and family factors affect reading performance of Grade 4 students in Azerbaijan?

\section{METHODS}

\section{Research design and data}

This study conducts a secondary analysis of the Progress in International Reading Literacy Study (PIRLS) 2016 data. Conducted every five years since its inception in 2001, PIRLS assesses the children's reading achievement in their fourth year of schooling. PIRLS 2016 is the fourth assessment in the current cycle. There were 61 participants in PIRLS 2016, including 50 
countries and 11 benchmarking entities (Mullis, Martin, Foy, \& Hooper, 2017). Azerbaijan participated in PIRLS twice: in 2011 and 2016.

The PIRLS 2016 uses a two-stage random sample design, with a sample of schools drawn as a first stage and one or more intact classes selected from each of the schools as a second stage (Martin, Mullis, \& Hooper, 2017). A total of 5,994 Grade 4 students (3,160 boys and 2,834 girls) from 170 schools participated in PIRLS in Azerbaijan. This study analyzed achievement data and background questionnaire data from the 5,994 Grade 4 students. The data were collected by PIRLS 2016 Student Questionnaire and PIRLS 2016 Learning to Read Survey (Home) Questionnaire.

\section{Variables}

Dependent variable. Reading achievement score (five plausible values) at fourth grade level on the PIRLS 2016 was the dependent variable in the study. PIRLS 2016 use a matrix-sampling booklet design such that each student responds only to a part of the PIRLS item pool. Given the complexities of the data collection and the need to have student scores on the entirety of each assessment for analysis and reporting purposes, PIRLS uses item response theory (IRT) scaling to describe student performance and to provide accurate measures of trends. Since each student responds to a subset of the assessment items only, the PIRLS scaling approach uses multiple imputation-or plausible values-methodology to obtain reading proficiency scores for all students (Martin et al., 2017). The PIRLS International Database provides five estimates of each student's score (plausible values) on reading achievement scale, and the variability between them captures the uncertainty in the scale estimation process (Foy, 2018). These five plausible values are jointly analyzed as the outcome variable.

Independent variables. Table 1 presents variables that were selected for the current analyses.

\section{Data analysis}

For purposes of data analysis, the International Database Analyzer (IDB) (version 4.0.30) was used. Developed by the International Association for the Evaluation of Educational Achievement (IEA) the IDB Analyzer is an interface for SPSS and SAS (Foy, 2018). The IDB Analyzer was used to perform the computations for each plausible value, produce estimates of average achievement and correct standard errors (Foy, 2018).

\section{RESULTS}

Table 2 shows zero-order correlations between student gender, student confidence in reading, student liking reading, home resources for learning, preschool attendance, and reading achievement. There are positive correlations between student gender and achievement $(r=0.09$, $P<0.01)$, student confidence and achievement $(r=0.31, P<0.01)$, student liking reading and achievement $(r=0.18, P<0.01)$, home resources for learning and achievement $(r=0.30$, $P<0.01)$, and preschool attendance and achievement $(r=0.16, P<0.01)$.

Regression results in Table 3 provide coefficients for each of the variables utilized in the current analysis. 
Table 1. Selection of variables from the PIRLS 2016 home and student questionnaires

\begin{tabular}{|c|c|c|}
\hline Index/Question & Source & Response options \\
\hline Home resources for learning & $\begin{array}{c}\text { Learning to Read survey (home } \\
\text { questionnaire)/Student } \\
\text { questionnaire }\end{array}$ & $\begin{array}{l}\text { Students were scored according } \\
\text { to their own and their parents' } \\
\text { responses concerning the } \\
\text { availability of resources (many } \\
\text { resources, few resources and } \\
\text { some resources) on the Home } \\
\text { Resources for Learning scale. }\end{array}$ \\
\hline $\begin{array}{l}\text { Students attended preprimary } \\
\text { education }\end{array}$ & $\begin{array}{l}\text { Learning to Read survey (home } \\
\text { questionnaire) }\end{array}$ & $\begin{array}{c}\text { Response options ranged from } \\
\text { Did not attend, less than a year, } 1 \\
\text { year, } 2 \text { years, } 3 \text { years or more. } \\
\text { The variable was recorded as } \\
\text { dichotomous variable with a } \\
\text { value of } 0 \text { for did not attend and } \\
1 \text { for attended preprimary } \\
\text { education }\end{array}$ \\
\hline Student gender & Student questionnaire & $\begin{array}{l}\text { Response options ranged from } 1 \\
\text { for girls and } 2 \text { for boys. The } \\
\text { variable was recorded as } \\
\text { dichotomous variable with a } \\
\text { value of } 0 \text { for boys and } 1 \text { for girls }\end{array}$ \\
\hline Students like reading & Student questionnaire & $\begin{array}{l}\text { Students were scored on the } \\
\text { Students Like Reading scale } \\
\text { according to their degree of } \\
\text { agreement with the statements } \\
\text { (very much like reading, } \\
\text { somewhat like reading, do not } \\
\text { like reading) and how often they } \\
\text { did reading activities outside of } \\
\text { school. }\end{array}$ \\
\hline Students confident in reading & Student questionnaire & $\begin{array}{l}\text { Students were scored according } \\
\text { to their degree of agreement with } \\
\text { statements on the Students } \\
\text { Confident in Reading scale (very } \\
\text { confident, somewhat confident } \\
\text { and not confident) }\end{array}$ \\
\hline
\end{tabular}

Evidence from the current study shows that all student and family effects utilized in the study have a strong influence on student reading achievement. Overall, the model explains 17\% of the variance in student reading achievement.

The student characteristics are important predictors of reading literacy performance. Student liking reading and student confidence in reading are positively associated with student reading achievement (difference of about 4 and about 11 points, respectively). Female students perform better in reading than males (difference of 9 points). 
Table 2. Correlation coefficients for Grade 4 students in Azerbaijan

\begin{tabular}{|c|c|c|c|c|c|c|}
\hline Variable & $\begin{array}{l}\text { Student } \\
\text { gender }\end{array}$ & $\begin{array}{l}\text { Student } \\
\text { confidence in } \\
\text { reading }\end{array}$ & $\begin{array}{l}\text { Student } \\
\text { liking } \\
\text { reading }\end{array}$ & $\begin{array}{l}\text { Home } \\
\text { resources for } \\
\text { learning }\end{array}$ & $\begin{array}{l}\text { Pre-school } \\
\text { attendance }\end{array}$ & $\begin{array}{l}\text { Reading } \\
\text { achievement }\end{array}$ \\
\hline Student gender & 1 & $0.09^{\star *}$ & $0.11^{\star \star}$ & 0.00 & -0.02 & $0.09^{* *}$ \\
\hline $\begin{array}{l}\text { Student } \\
\text { confidence } \\
\text { in reading }\end{array}$ & $0.09^{* *}$ & 1 & $0.31^{\star *}$ & $0.17^{\star \star}$ & $0.08^{\star *}$ & $0.31^{* *}$ \\
\hline $\begin{array}{l}\text { Student liking } \\
\text { reading }\end{array}$ & $0.11^{\star \star}$ & $0.31^{\star *}$ & 1 & $0.10^{\star \star}$ & $0.03^{*}$ & $0.18^{\star *}$ \\
\hline $\begin{array}{l}\text { Home } \\
\text { resources for } \\
\text { learning }\end{array}$ & 0.00 & $0.17^{\star *}$ & $0.10^{\star *}$ & 1 & $0.30^{\star \star}$ & $0.30^{* *}$ \\
\hline $\begin{array}{l}\text { Preschool } \\
\text { attendance }\end{array}$ & -0.02 & $0.08^{\star *}$ & $0.03^{*}$ & $0.30^{\star \star}$ & 1 & $0.16^{* *}$ \\
\hline $\begin{array}{l}\text { Reading } \\
\text { achievement }\end{array}$ & $0.09^{\star *}$ & $0.31^{\star *}$ & $0.18^{\star *}$ & $0.30^{\star \star}$ & $0.16^{\star *}$ & 1 \\
\hline
\end{tabular}

${ }^{*} P<0.05$.

${ }^{* *} P<0.01$.

Table 3. Regression coefficients for Grade 4 students in Azerbaijan

\begin{tabular}{lcr}
\hline Variable & Regression coefficient & SE \\
\hline Student gender & $9.41^{\star *}$ & 3.25 \\
Student confidence in reading & $10.54^{\star *}$ & 1.23 \\
Student liking reading & $3.83^{\star *}$ & 1.16 \\
Home resources for learning & $13.36^{\star *}$ & 1.37 \\
Preschool attendance & $11.21^{\star}$ & 4.96 \\
\hline
\end{tabular}

${ }^{\star} P<0.05$.

${ }^{* *} P<0.01$.

Next, our model shows that family also has strong impact on student reading achievement. Home educational resources are positively associated with reading achievement (difference of 13 points). Student preschool attendance is also positively associated with reading literacy performance (difference of 11 points).

\section{DISCUSSION}

Findings from the study provide evidence for importance of student and family effects in predicting increased reading achievement scores. These findings have important policy implications as they show which factors can be addressed by policy interventions to improve student achievement in reading.

This study found the importance of student factors in predicting reading literacy scores. The study demonstrated that gender differences in reading literacy scores in the PIRLS sample of 
Grade 4 students in Azerbaijan favored females. Policy analysts need to develop interventions to reduce gender effects in reading literacy scores. It is suggested that schools can attempt to decrease gender differences by improving the perception of the usefulness of reading for all students.

In addition, the findings of the study suggest significant relationship between student liking reading and confidence in reading and reading literacy scores. Therefore, people engaged in educational process could think of creating classroom experiences aimed at improving student liking reading and student confidence in reading. It is important to increase liking reading and confidence in reading by encouraging and motivating students to read and helping students realize the link between their efforts and performance.

This study demonstrated the family effects on reading literacy scores. Through policies to address changes in the socio-economic status of families and their home educational resources are limited, certain educational interventions (e.g., improving parents' perceptions of the importance of preschool education) may be beneficial to student performance. Government and policymakers should consider the findings of the current study as an additional evidence to advocate for public preschool attendance.

\section{CONCLUSION}

Many studies have discussed the relative importance of student and family factors for student reading performance. However, few studies conducted in developing countries examined multiple predictors of student performance. This study examined the effects of student and family factors on reading literacy scores through regression analysis using PIRLS 2016 data. The study found that selected student characteristics (gender, liking reading, and confidence in reading) and family factors (home resources for learning, preschool attendance) were consistently related to Grade 4 reading achievement in Azerbaijan. These findings are in line with previous research that determined the importance of student and family factors for reading achievement (Alivernini, 2013; Costa \&Araujo, 2017; Geske \& Ozola, 2008; Leino et al., 2004; Linnakyla et al., 2004).

This study proposed specific recommendations related to the effects of various factors on reading literacy scores. Based on the findings of this study, policy analysts may consider some specific interventions that can be implemented in the frame of reform efforts. Such policies implemented along with reform efforts, are important for improvement of educational quality in Azerbaijan.

In sum, the student reading performance in Azerbaijan has slightly increased since 2011, but it is too early to claim that these improvements are attributable to recent policy changes, like the implementation of the new National Curriculum, or special reading initiatives. Educational systems are too complex and slow to produce large-scale improvements within those systems. However, PIRLS studies are helpful in identifying how policy measures affect student performance, and in the future PIRLS cycles, researchers and policy analysts will produce more substantial conclusions relating recent changes in policy to changes in reading achievement in Azerbaijan. 


\section{ACKNOWLEDGMENT}

The author declares no conflict of interest.

\section{ABOUT THE AUTHOR}

Lala Ganiyeva has a Ph. D. in Educational Leadership and Policy Analysis from the University of Missouri. Her research interests are grounded in more than 20 years of practice as an educator, consultant, policy analyst, and scholar. Her practice and scholarship are broad and encompass a number of various areas. She focuses upon educational change and training in international context and examines the following topics:

- Teacher and school effectiveness

- School, student and family factors associated with student performance

- Educational leadership

\section{REFERENCES}

Alivernini, F. (2013). An exploration of the gap between highest and lowest ability readers across 20 countries. Educational Studies, 39 (4), 399-417. https://doi.org/10.1080/03055698.2013.767187.

Cheung, W. M., Lam, W. I. J., Au, D. W. H., \& So, W. W. Y. (2017). Explaining student and home variance of Chinese reading achievement of the PIRLS 2011 Hong Kong. Psychology in Schools, 5(9). https://doi. org/10.1080/01443410.2016.1242712.

Costa, P., Almeida, P., \& Araujo, L. (2012). Reading literacy in EU countries: Evidences from PIRLS. Retrieved from http://publications.jrc.ec.europa.eu/repository/bitstream/JRC86217/pirls_report_final. pdf.

Costa, P., \& Araujo, L. (2018). Skilled students and effective schools: Reading achievement in Denmark, Sweden, and France. Scandinavian Journal of Educational Research, 62(6), 850-864. https://doi.org/10. 1080/00313831.2017.1307274.

Foy, P. (Eds.). (2018). PIRLS 2016 user guide for international database. Retrieved from Boston College, TIMSS \& PIRLS International Study Center website: https://timssandpirls.bc.edu/pirls2016/ international-database/downloads/P16_UserGuide.pdf.

Geske A., \& Ozola A. (2008). Factors influencing reading literacy at the primary school level. Problems of Education in the 21st Century, 6, 71-77.

Hogrebe, N., \& Strietholt, R. (2016). Does non-participation in preschool affect children's reading achievement? International evidence from propensity score analysis. Large- Scale Assessments in Education, 4(2). https://doi.org/10.1186/s40536-016-0017-3.

Leino, K., Linnakyla, P. \& Malin, A. (2004). Finnish students' multiliteracy profiles. Scandinavian Journal of Educational Research, 48(3), 251-270. https://doi.org/10.1080/00313830410001695727.

Linnakyla, P, Malin, A., \& Taube, K. (2004). Factors behind low reading literacy achievement. Scandinavian Journal of Educational Research, 48(3), 231-249. https://doi.org/10.1080/00313830410001695718. 
Ma, X. (2008). Within-school gender gaps in reading, mathematics, and science literacy. Comparative Education Review, 52 (3), 437-460. doi:10.1086/588762.

Martin, M. O., Mullis, I. V. S., \& Hooper, M. (Eds). (2017). Methods and procedures in PIRLS 2016. Retrieved from Boston College, TIMSS \& PIRLS International Study Center website: https://timssandpirls.bc.edu/publications/pirls/2016-methods.html.

Mullis, I. V. S., Martin, M. O., Foy, P., \& Hooper, M. (2017). PIRLS 2016 international results in reading. Retrieved from Boston College, TIMSS \& PIRLS International Study Center website: http://timssandpirls.bc.edu/pirls2016/international-results/.

Mullis, I. V. S., Martin, M. O., Goh, S., \& Prendergast, C. (Eds). (2017). PIRLS 2016 Encyclopedia: Education policy and curriculum in reading. Retrieved from Boston College, TIMSS \& PIRLS International Study Center website: http://timssandpirls.bc.edu/pirls2016/encyclopedia/.

Park, H. (2008). Home literacy environments and children's reading performance: A comparative study of 25 countries. Educational Research and Evaluation, 14(6), 489-505. https://doi.org/10.1080/ 13803610802576734.

Perie, M., Grigg, W., \& Donahue, P. (2005). The nation's report card: Reading 2005 (NCES 2006-451). U.S. Department of Education, National Center for Education Statistics. Washington, DC: U.S. Government Printing Office.

Petscher, Y. (2010). A meta-analysis of the relationship between student attitudes towards reading and achievement in reading. Journal of Research in Reading, 33(4), 335-355. https://doi.org/10.1111/j.14679817.2009.01418.x.

Quirk, M., Schwanenflugel, P. J., \& Webb, M. (2009). A short-term longitudinal study of the relationship between motivation to read and reading fluency skill in second grade. Journal of Literacy Research, 41, 196-227. https://doi.org/10.1080/10862960902908467.

Sainsbury, M., \& Schagen, I. (2004). Attitudes to reading at ages nine and eleven. Journal of Research in Reading, 27, 373-386. https://doi.org/10.1111/j.1467-9817.2004.00240.x.

Schleicher, A. (2014). Equity, excellence and inclusiveness in education: Policy lessons from around the world. Paris: OECD Publishing.

van der Voort, T. H. A. (2001). Television's impact on children's leisure time reading and reading skills. In L. Verhoeven, \& C. Snow (Eds), Literacy and motivation: Reading engagement in students and groups (pp. 95-121). Mahwah, NJ: Lawrence Erlbaum.

Wagemaker, H., Taube, K., Munck, I., Kontogiannopoulou-Polydorides, G., \& Martin, M. (1996). Are girls better readers? Amsterdam, Netherlands: IEA.

Open Access. This is an open-access article distributed under the terms of the Creative Commons Attribution-NonCommercial 4.0 International License (https://creativecommons.org/licenses/by-nc/4.0/), which permits unrestricted use, distribution, and reproduction in any medium for non-commercial purposes, provided the original author and source are credited, a link to the CC License is provided, and changes - if any - are indicated. 